Research Article

\title{
Survey and Comparative Study on Treatment of Psoriasis
}

\section{Aishwarya Madhav르, Rohan Sawant ${ }^{2}$, Pratik Desai ${ }^{3}$, Harish Mhapsekar ${ }^{3}$, Sagar Minat ${ }^{3}$, Dr. Dattatraya Shinkar ${ }^{4}$, Dr. V. A. Jagtap ${ }^{4}$} 1 Department of Pharmaceutics, Yashwantrao Bhonsale College of Pharmacy, University of Mumbai, Maharashtra, India. 2 Yashwantrao Bhonsale College of Pharmacy, University of Mumbai, Maharashtra, India.

*Corresponding author's E-mail: madhavaishwarya127@gmail.com

Received: 14-05-2021; Revised: 22-07-2021; Accepted: 30-07-2021; Published on: 15-08-2021.

\section{ABSTRACT}

Psoriasis is autoimmune chronic inflammatory disease which has affected $2 \%$ of total population but varies according to region. The main purpose of this work to conduct survey and comparatively study of various antipsoriatic drugs for their therapeutic dose , potency \& their side effects . so that it will help in correct choice of medication to treat it. Different classes of drugs have been compared such as biologic \& non biologic etc. Now a days combination therapy is also used which is also compared in this article. A survey-based study was conducted amongst the patients, pharmacists, \& physicians in March 2021. A questionnaire was prepared. For the patient survey we had focused on various parameters and prepared a questionary. Later we had taken the print out and we asked that questions to patient, pharmacists and physicians. Our main aim for conducting the survey was to segment the patient on the basis of their age, gender, also treatment they have been taking. From this survey we conclude that the maximum number of peoples suffering from psoriasis was above 40 years $\&$ also it was found that more number of females patients are suffering from psoriasis. We found that people suffering from psoriasis was undergoing with allopathic treatment. We had looked for medication of both allopathic as well as ayurvedic in the market \& studied the market segment on the basis of which fomulation has been prescribed by physician, so we found that allopathic treatment has been prescribed by doctor. Plaque psoriasis was most common in patient $\&$ also from this survey we found that biologic therapy was most costly than other therapies and this therapy mostly prescribed by doctor. From above one can conclude that, most of the treatment, methods and drugs available in the market gives symptomatic relief or are effective towards only one of the causes of psoriasis which fails in treating psoriasis. The combination therapy are used nowadays for treating psoriatic arthritis, but if these combinations are multitargeted and if it treating the multiple causes then it might be useful for chronic psoriasis treatment.

Keywords: Psoriasis, Autoimmune disease, Treatment, Antipsoriatic Drug, Combination therapy, biologic therapy, Psoriatic Arthritis

QUICK RESPONSE CODE $\rightarrow$

DOI:

10.47583/ijpsrr.2021.v69i02.016

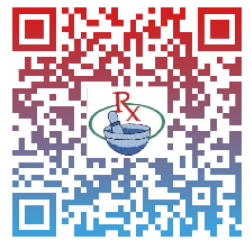

DOI link: http://dx.doi.org/10.47583/ijpsrr.2021.v69i02.016

\section{INTRODUCTION}

soriasis is an immune-mediated disease (disease with an unclear cause that is characterized by inflammation caused by dysfunction of the immune system ) that causes inflammation in the body. ${ }^{1}$ There may be visible signs of the inflammation such as raised plaque ( plaque may look different for different skin type ) and scales on the skin. ${ }^{1,2,3}$ This occurs because the overactive immune system speeds up skin cell growth. Normal skin cell completely grows and shed (fall off) in a month. With psoriasis, skin cell does this in only three or four days. Instead of shedding, the skin cell piles up on the surface of the skin. Some people report that psoriasis plaque itch, burn and sting. Plaques and scales may appear on any part of the body. Although they are commonly found on elbows, knees, and scalp. ${ }^{1,4,5}$ Inflammation caused by psoriasis can impact other organs and tissues in the body.
People with psoriasis may also experience other health conditions $^{1}$. One in three people with psoriasis may also develop psoriatic arthritis. Signs of PsA include swelling, stiffness and pain in the joint and areas surrounding the joints. ${ }^{1,5}$

\section{Types of Psoriasis}

\section{Plaque psoriasis}

It is most common type of psoriasis it is also known as psoriasis vulgaris it is appear as raised, inflammed-red skin covered by silvery patchs and scales. Site of infection: Elbows knees sacrum scalp lower back hands and feet .6,7

\section{Guttate psoriasis}

It is characterized by erruption of small $(0.5-1.5 \mathrm{~cm}$ in diameter) papules over the upper trunk and proximal extremities. It is menifests at an early age also streptococcal throat infections frequently presedes or in concomitant with the onset or flare. ${ }^{8,9}$

\section{Inverse psoriasis}

Localized in the major skin folds such as the axilla the inguinal and inflammatory areas and sweating areas Scaling is usually minimal or absent and the lesions appear glossy smooth and bright red also it is commonly seen in obese client. $^{5}$ 


\section{Pustular psoriasis}

It is usually uncommon but mostly appear in adult also it appears as pus filled lesion surrounded by red skin also it seen in hands and feets it is serious condition so medical attention is required. ${ }^{10}$

\section{Erythrodermic psoriasis}

The disease affects all body parts erythema is most prominent feature with superficial scaling or peeling that may appear like burning.

Causes : sun burn allergic reaction strong coal product use. $^{10}$

\section{Nail psoriasis}

Commonly seen along with psoriatic arthritis it appear as pitting small bit nail yellow brown nail tender and painful nail with chalk like debris build up under nail keep the nail short and trimmed treated by steroid injected into nail and light therapy. ${ }^{11}$

\section{Psoriatic arthritis}

This is the condition which involves both psoriasis and joint inflammation. The most distinctive features of psoriatic arthritis are given as Distal interphalangeal joint arthritis and Dactylitis.12

\section{Causes of Psoriasis}

The disease is triggered by several factors and tends to worsen with time. Various factors that lead to the start of psoriasis are discussed below.

\section{Trauma}

The sites on the skin, which are exposed to the friction or minor trauma, such as the extensive areas of knees, elbow, etc are the areas prone to psoriasis. Psoriasis is known to be induced by various physical, chemical and inflammatory skin disruptions. These include abrasions, incisions, rubbing, shaving, etc.$^{13,14}$

\section{Infection}

Certain toxins, such as bacterial toxins that activate Tcells tend to induce the appearance of cutaneous lymphocyte antigen, which produces psoriatic lesions. The incidence of disease due to infection ranged from $15-76 \%$. A study is evidenced showing a strong correlation between psoriasis infections with S. pyro genes.$^{15}$

\section{Obesity}

Some study reports suggested that obesity is the causative agent of the disease, while some others revealed that psoriasis leads to obesity. Some studies suggest that adipocyte proliferation of pro-inflammatory cytokines leads to psoriasis. A study conducted by The Nurses Health Society (NHS) revealed that there is an outstanding relation between psoriasis and an increase in body mass index ${ }^{16,17}$

\section{Drugs}

Many drugs can initiate psoriasis including the intake of lithium, corticosteroids, antimalarial, $\beta$-blockers, etc $\cdot{ }^{18} \mathrm{~A}$ potential $\beta$-blocker practolol is the most common drug known to cause psoriasis. Other $\beta$-blockers, which are non-cardio selective, such as propranolol, pindolol, etc are reported to cause psoriatic lesions. ${ }^{19}$

\section{Stress}

Stress is reported to play a role in inducing the disease. The time gap between the onset of disease and stress episode is generally less than one month. Verhoeven et al. suggested that serious psoriasis conditions arise from different behavioral patterns, such as scratching and stress. ${ }^{20}$ The mechanism of this can be attributed to the changes occurring during the regulation of stress and catecholamine's . ${ }^{21}$

\section{Smoking}

The incidence of the disease is greater in the case of smokers, as evident from a dose-response relationship. ${ }^{22}$ The prevalence of the disease is higher in women than in men. In women, the risk is 2.5 times greater than nonsmokers; in men, the risk is 1.7 times greater as compared to non-smokers. ${ }^{23}$

\section{Endocrine Factors}

Certain hormones, such as androgens, prolactin, and thyroid hormones are known to have a direct influence on psoriasis. The two major factors in the onset of disease are at puberty and menopause. ${ }^{24} \mathrm{~A}$ study in about 65 women suggested that the disease remains unaffected in $40 \%$ of the pregnancies.$^{25}$

\section{Methodology}

We had conducted three kind of survey which includes physician, pharmacist and the patients. For the patient survey we had focused on various parameters and prepared a questionary. Later we had taken the print out and we asked that questions to patient, pharmacists and physicians. Our main aim for conducting the survey was to segment the patient on the basis of their age, gender, also treatment they have been taking.

Following were the various question we have included in the form that was to be filled by the patient.

1) Age at which psoriasis began?

2) Did anything happen to bring on your psoriasis?

3) Is your psoriasis limited to specific areas of your body?

4) Does your psoriasis affect certain parts of your body that are more troublesome to you than other areas?

5) Which type of treatment you had taken or taking? 
6) What type of treatments do you use for psoriasis? Do you feel that these treatments are the best available?

7) Has your psoriasis increased in severity since initial onset?

Following were the various question we have included in the form that was to be filled by the Physician.

1) What are the symptoms for psoriasis?

2) What are the causes for psoriasis?

3) Psoriasis is Acute or Chronic? What do you think?

4) What are the better therapies for treating psoriasis?

5) What type of medicines you prescribed for patients?

6) Which type of diet you suggest for patients?

7) How do patients other medical conditions effect on psoriasis?

In physician survey, we analyze that physician mostly prescribed allopathic treatment. In severe cases combination therapy mostly prescribed. There are three types of treatments viz topical treatments, light therapy (phototherapy) and oral medication. Topical treatments like (creams, lotions, gels, ointments, moisturizers applied to the skin) are usually the first line treatment and they help to reduce the inflammation of skin.

Following were the various question we have included in the form that was to be filled by the Pharmacist.

1) What are the symptoms for psoriasis?

2) What are the causes for psoriasis?

3) Psoriasis is Acute or Chronic? What do you think?

4) Ayurvedic treatment is better or not ?

5) If I start biologic, do I need to stop my current regimen for the treatment for my psoriasis?

6) Any food related problem is responsible for psoriasis?

7) What should be criteria to be followed by patient in his daily routine?

8)How long will patient need to be taken a medication?

In the pharmacy survey, we had looked for the medication both allopathic as well as ayurvedic available in the market and studied the market segment on the basis of content used and also which formulation has been prescribed by the doctors. Following was the format for pharmacy survey.

\begin{tabular}{l|l|l|l|l|}
\hline $\begin{array}{l}\text { Brand } \\
\text { Name }\end{array}$ & $\begin{array}{c}\text { Company } \\
\text { Name }\end{array}$ & Ingredients & $\begin{array}{c}\text { Packaging } \\
\text { Quantity }\end{array}$ & MRP \\
\hline & & & \\
\hline SCOPE & & & \\
\hline
\end{tabular}

\section{For the Combination therapy}

IL-12 \& IL- 23 inhibitors are proving to be efficiently used drug with lesser side effects. Ustekinumab IL-inhibitor is available in the market as a sustained released subcutaneous injection. Also, the DMARDS \& photo therapy are being used as a first line drugs for curing psoriasis. TNF- alpha inhibitor are the category of the drugs which prevent the inflammatory response in the body. If the combination formulation of IL- inhibitor and TNF-Alpha inhibitors are made as the sustained released dosage form by using the novel drug delivery system technology, this can be helpful as it will target more than one cause and help in curing the disease rapidly.

\section{RESULT AND DISCUSSION}

Psoriasis, a chronic, recurrent inflammatory skin disorder. The most common type, called plaque psoriasis (psoriasis vulgaris), is characterized by slightly elevated reddish patches or papules (solid elevations) covered with silvery white scales. In most cases, the lesions tend to be symmetrically distributed on the elbows and knees, scalp, chest, and buttocks. Psoriasis is an immune-mediated (or autoimmune) disorder that occurs when immune cells known as T lymphocytes, or T cells, attack healthy skin cells in both the nonvascular horny outer layer of the skin and its deeper vascular layer. This attack causes the life span of the skin cells to shorten to about 3 to 5 days (skin cells normally live about 20 to 28 days) and forces the cells to reproduce more rapidly than normal. Treatment aims to remove scales and stop skin cells from growing so quickly. Topical ointments, light therapy and medication can offer relief. Steroid, Vitamin A derivative, Antiinflammatory, Immunosuppressive drug and Vitamin.

Apparent synergistic enhancement is seen with most paired combinations of the four major therapies: Acitretin, phototherapy (ultraviolet $B / p s o r a l e n$ plus ultraviolet A), cyclosporine, and methotrexate. Of those, only cyclosporine in combination with psoralen plus ultraviolet $A$ is contraindicated because of increased cancer risk. Combinations of each of those major therapies with topical agents (retinoids, steroids, vitamin $D$ derivatives, and others) have been used with varying efficacy and safety.

\section{- Patients survey based on Age}

According to survey, psoriasis can begin at any age, psoriasis has 2 peaks of onset, the first at age 20 to $30 y e a r s$ and later age 50 to 60 years .It affects men and women equally but is more common in non-hispanic whites Some patients are more prone to developing psoriasis, especially if there is a family member with psoriasis. 
Fig no.1

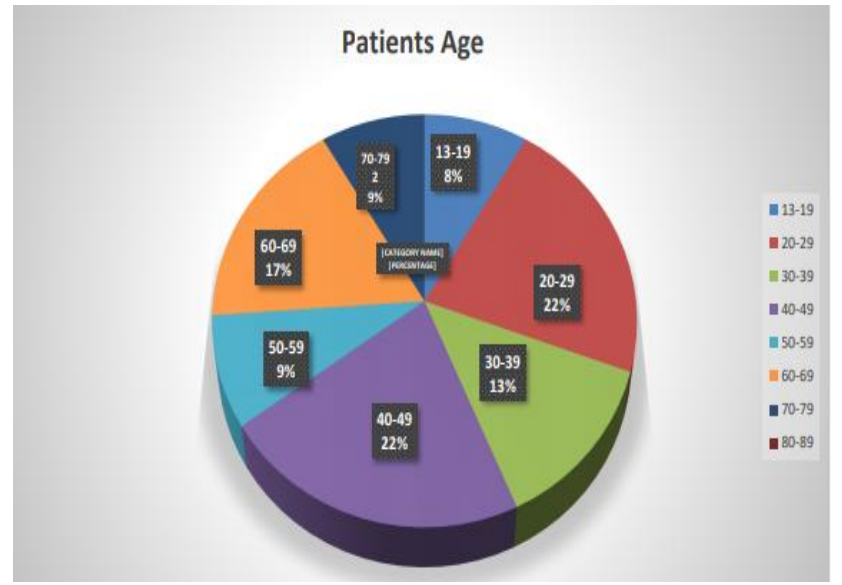

- Patient survey on the basis Gender Wise proportion

When it come to gender wise differentiation, we have found that mostly female suffering from these disease This is because of the rush of hormones can cause or worsen skin problems, including teenage acne and psoriasis. High levels of estrogen after your first period may cause certain skin cells to reproduce too quickly Since hormone levels group and down during your menstrual cycle, so can your psoriasis symptoms. So that Psoriasis appears to be slightly more prevalent among women than among men.

\section{Fig no.2}

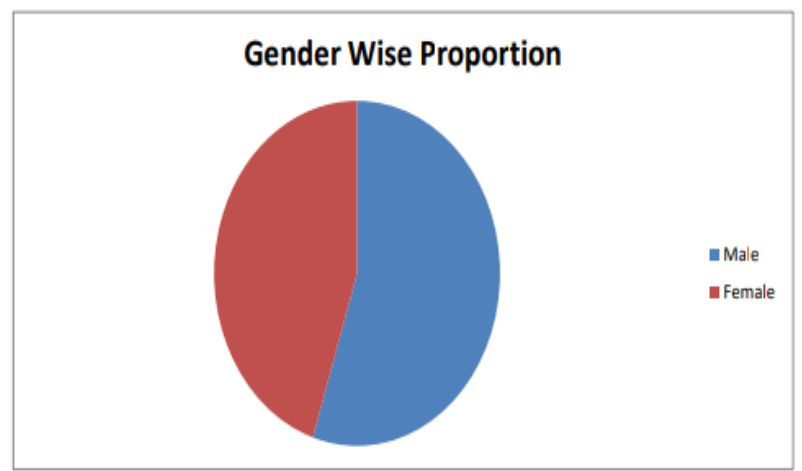

\section{- Patient Survey on Basis of Treatment undergoing}

As various treatment option are available for treating psoriasis. Survey was conducted regarding the treatment therapy the patient were undergoing. From the survey it can be concluded that most people suffering with psoriasis tends to choose ayurvedic treatment (40\%) for getting benefit. Only 35\% patient choose allopathic treatment for curing the diseases. Also from the survey it has been seen that from allopathic treatment topical therapy, phototherapy and methotrexate were mostly prescribed by the doctor.

Fig .no 3

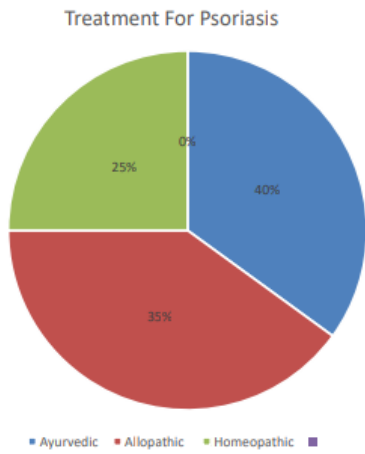

- Survey based on formulation available

In this pharmacy survey, the main aim was to obtain the data regarding the allopathic and ayurvedic medicine available in market for curing the psoriasis. From the survey it has come to our notice that $54 \%$ of the pharmacy contain allopathic medicine and these medicine prescribed by the doctors . Rest $46 \%$ sell ayurvedic medication just to relieve the symptoms of psoriasis.

\section{Fig.no 4}

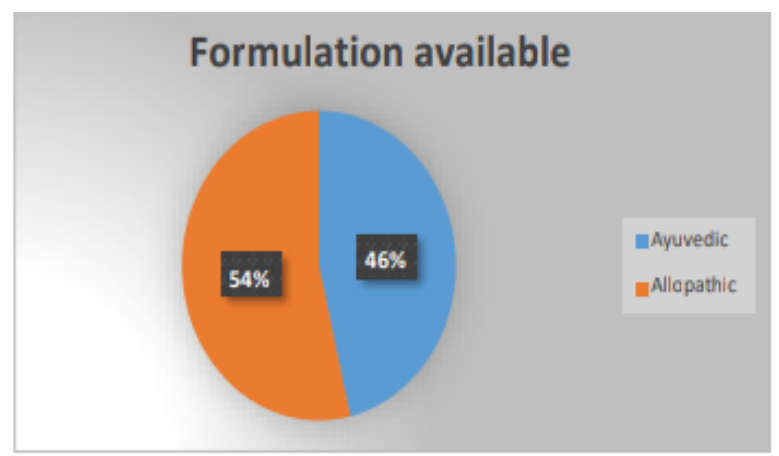

\section{- Survey based on type of psoriasis}

According to white scaly layer.survey, plaque psoriasis was the most common form of psoriasis. An estimated 80 to 90 percent of people with psoriasis have plaque psoriasis. It's characterized by thick red patches of skin, often with a silver or

Fig. no.5

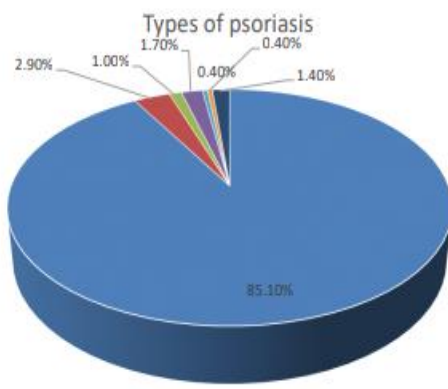

\section{Survey as per cost of therapy}

According to survey we have found that biologic therapy is more costly than other therapy. 
Fig. no. 6

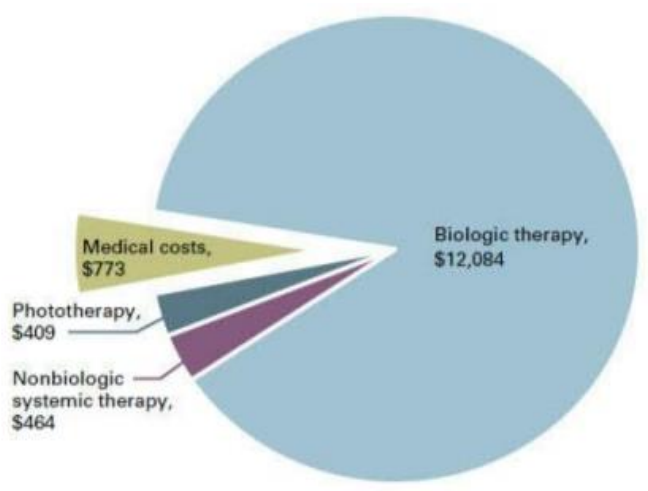

\section{Pathophysiology}

There are two main hypotheses about the development of psoriasis. The first hypothesis considers psoriasis as primarily a disorder of excessive growth and reproduction of skin cells, in which psoriasis is a manifestation of a fault of the epidermis and its keratinocytes.

The second hypothesis views the disease as an immunemediated disorder in which the excessive reproduction of skin cells is secondary to factors produced by the immune system.

The pathogenesis of psoriasis can be explained by dysregulation of immunological cell function as well as keratinocyte proliferation/differentiation. Recently, the immunological pathomechanism has been clarified substantially. Whereas T-helper (Th)1 overactivation was thought to induce occurrence of psoriasis, it has been demonstrated that Th17 cells play a key role. Th17 development is maintained by interleukin (IL)-23 mainly pro-duced by dendritic cells. Th17 cells produce various cytokines, including IL-17A, IL-17F and IL-22. IL-17A and IL22 induce not only keratinocyte proliferation, but also tumor necrosis factor (TNF)-a, chemokine ( $\mathrm{C}-\mathrm{X}-\mathrm{C}$ motif) ligand (CXCL) 1 and CXCL8 production. TNF-a accelerates the infiltration of inflammatory cells, including lymphocytes, monocytes and neutrophils, from the peripheral blood into skin with dendritic cell activation.

In addition, antimicrobial peptides are overexpressed in psoriatic skin lesions, and the antimicrobial peptide, LL-37, activates dendritic cells, which leads to the development of inflammation. Furthermore, activation of nuclear factor-jB signal induces the expression of keratins 6 and 16 in keratinocytes, which are associated with acanthosis and reduced turnover time in the epidermis.

\section{Psoriasis Factor}

\section{Role of helper T cell}

Activation and differentiation of $T$ cell subsets are maintained by IL-12 and IL-23, which appear to be produced mainly from myeloid DC subsets in the skin. Psoriasis lesions contain T cells that produce IFN- $\gamma, \mathrm{IL}-17$, and IL-22, produced by Th1, Th17, and Th22, respectively. There are also $\mathrm{CD} 8+\mathrm{T}$ cell populations that make the same types of cytokines. In response to these cytokines, keratinocytes in the skin upregulate the production of mRNAs, which lead to the formation of many proinflammatory products. Chemokines produced by keratinocytes cause the migration of many leukocyte subsets (e.g., dendritic cells (DCs) and neutrophiles ..$^{26,27}$

\section{Role of Dendritic Cells}

TNF $\alpha$ and nitric oxide synthase isoform (iNOS)-producing inflammatory dendritic cells infiltrate psoriatic skin. These dendritic cells have the ability to activate T-cells to differentiate into Th1 and Th17 cell lines. Macrophages and innate immune cells, as well as an increased number of endothelial cells (angiogenesis), have also been implicated in the pathogenesis of psoriasis.psoriasis. Inflammatory myeloid dendritic cells release IL-23 and IL12 to activate IL-17-producing T cells, Th1 cells, and Th22 cells to produce numerous psoriatic cytokines, which include IL-17, IFN- $\gamma$, TNF, and IL-22. These cytokines mediate effects on keratinocytes to augment psoriatic inflammation. ${ }^{28,} 29$

\section{TNF- ALPHA (TUMOR NECROSIS FACTOR)}

TNF- $\alpha$ is involved in many inflammatory cutaneous diseases, including psoriasis. Several different cell can produce TNF- $\alpha$ in the context of skin inflammation, including keratinocytes, macrophages, T cells (Th1, Th17, and Th22 cells), and psoriatic DCs (particularly TIP-DCs) .The key effects of TNF- $\alpha$ are regulating the antigenpresenting ability of DCs and stimulation of T-cell infiltration. It has a variety of effects because there are two types of TNF receptors (TNFR), TNFR1 and TNFR2. TNFR1 is expressed on nearly all cell types, whereas TNFR2 is present predominantly on endothelial cells and hematopoietic cells. TNF- $\alpha$ acts in part by increasing the elevated level of active, phosphorylated NF-kB, a crucial transcription factor involved in psoriatic pathogenesis. TNF- $\alpha$ possesses proinflammatory properties; it activates the expression of C-reactive protein and several cytokines such as IL-6 (which induces keratinocyte hyperproliferation and T-cell proliferation) and IL-23 (which is a potential mediator synthesized from DCs in psoriasis to stimulate IL-17 production). TNF- $\alpha$ also induces several chemokines including CXCL8/IL-8 (which recruits neutrophil infiltration) and CCL20 (which recruits myeloid DCs and Th17 cells). Therefore, TNF- $\alpha$ is an important regulator of the IL-23/Th17 axis in psoriasis. ${ }^{30}$

\section{NF-kB Pathway}

Genes in the NF-KB pathway are associated with psoriasis. NF-KB is an inhibitor of the NF-KB pathway. After the initiation of NF-KB signaling by cytokines such as TNFalpha, IKB is phosphorylated by IKB kinase (IKK) and subsequently targeted for proteosomal degradation. The degradation of IKB releases NF-KB for translocation to the nucleus, consequently leading to gene expression for proinflammatory products. ${ }^{31,32,33}$ 


\section{JAK-STAT pathway}

The (JAK-STAT) pathway plays a significant role in intracellular signaling of cytokines of numerous cellular processes, important in both normal and pathological states of immune-mediated inflammatory diseases. Particularly in psoriasis, where the interleukin(IL)-23/IL-17 axis is currently considered the crucial pathogenic pathway, blocking the JAK-STAT pathway with small molecules would be expected to be clinically effective. ${ }^{34}$

\section{Interferons (IFNs)}

Type I interferons (IFNs), IFN- $\alpha$ and IFN- $\beta$, can suppress viral replication and stimulate immune reactions in response to viral infections; thus, they are potential mediators of antiviral host defense. Activated plasmacytoid dendritic cells ( $\mathrm{DDCs}$ ) preferentially produce type I IFNs following interactions between intracellular TLR7 and TLR9 with viral RNA and DNA. Type I IFN- $\alpha$ and IFN- $\beta$ are not expressed in the normal skin but are produced in virally infected skin where pDCs are present, as well as in skin wounds where mechanical injury stimulates infiltration of pDCs and in lesional psoriatic skin where pDC-derived type I IFNs are sustained.4. This stimulates myeloid DC phenotypic maturation and activation, enabling T-cell priming. IFN- $\gamma$ acts on psoriatic keratinocytes and endothelial cells, leading to the activation and production of antimicrobial peptides (e.g., LL-37 cathelicidin and $\beta$-defensins). IFN- $\gamma$ induces the cross phosphorylation of Janus kinase 1 (JAK1) and JAK3, resulting in the ownstream activation of STAT3. Subsequent activation of STAT transcription factors is important for cell growth and is efficient for regulating many genes expressed in psoriatic lesions. IFN- $\gamma$ promotes the release of cytokines (IL-23, IL-1 and chemokines (CXCL10, CXCL11), as well as the expression of adhesion molecules from DCs, T cells, keratinocytes, and endothelial cell., thus promoting the recruitment of inflammatory cells to lesional plaques. ${ }^{35,36}$

\section{Interleukins}

\section{IL-12/IL-23}

IL-12 and IL-23 are heterodimeric pleiotropic proteins that share a common p40 subunit and are thought to be essential for controlling the differentiation of Th1 and Th17 cells, respectively. The second distinct subunit of IL12 is the 355 subunit, and the second unique subunit of IL23 is the p19 subunit (encoded by IL23A). Expression of the p19 and p40 subunits was found to be significantly increased in psoriatic skin lesions, while the p35 subunit was not, suggesting that $\mathrm{IL}-23$ is important in the pathogenesis of psoriasis. IL-23 and IL-12 are primarily secreted by DCs and macrophages and play a crucial role in psoriatic pathogenesis by regulating Th17 and Th1 cells, including the activation and differentiation of effector $\mathrm{T}$ cells, stimulation of keratinocytes, and upregulation of TNF- $\alpha$ expression in psoriatic plaques. IL-23 binds to IL$23 \mathrm{R}$, which is correlated with Jak2 and Tyk2. Binding of its receptor stimulates a signaling circuit via STAT3 activation. ${ }^{37,38,39}$

\section{IL -17}

IL-17, the main cytokine effect or of Th17 cells, is an important cytokine in the pathogenesis of psoriasis. Neutrophils, mast cells, and natural killer (NK) cells also produce IL-17. It is thought to be a proximal regulator of psoriatic cutaneous inflammation and plays a key role in bridging the innate and adaptive immune responses. The IL-17 family comprises six subsets of homo- and heterodimeric cytokines: IL-17A, IL-17B, IL-17C, IL-D, IL$17 E$, and IL-17F. IL-17A and IL-17F are regarded as the most relevant subtypes in psoriasis. ${ }^{40,41,42,43}$

\section{IL-22}

IL-22 belongs to the IL-10 family of cytokines, and its receptor (IL-22R) is a complex of two chains (IL-10R and IL22RA1), which are exclusively expressed on epithelial cells such as keratinocytes. Elevated levels of IL-22 mRNA in the lesional skin of psoriasis and serum IL-22 have been observed . ${ }^{44}$

\section{IL-9}

IL-9 is a member of the IL-2 cytokine family. IL-9 is a proinflammatory cytokine that stimulates the production of IL-17, IL-13, IFN- $\gamma$, and TNF- $\alpha$ in psoriasis. Both Th9 and Th17 cells are sources of IL-9. ${ }^{37}$

\section{IL-33}

Interleukin-33 is a recently discovered mediator of the IL1 family. IL-33 mRNA is constitutively expressed in several tissues but is predominantly distributed in epithelial cells, keratinocytes, fibroblasts, DCs, smooth muscle cells, and macrophages. Interestingly, IL-33 specifically localizes to the nucleus of endothelial cells along the vessels and epithelial cells of tissue exposed to the environment. The IL-33 receptor is selectively expressed on various cell types, including T-helper-cell (Th) type 2, mast cells, eosinophils, basophils, dendritic cells, group 2 innate lymphoid cells, keratinocytes, and invariant NKT cells . IL33 can act both as a released cytokine, activating ST2L, and as a nuclear-binding factor, regulating gene transcription. ${ }^{45}$

\section{Conventional treatment for Psoriasis}

The conventional treatment for psoriasis depends upon the severity and location of lesions. First line topical treatments were suggested for mild to moderate psoriasis. This includes corticosteroids, vitamin D3 analogues and calcipotriol betamethasone dipropionate combination products. Calcipotriol, a vitamin D3 analogue is the choice for plaque psoriasis and scalp psoriasis.

Around 57 adverse effects were reported in a randomized, double blind, right/left comparison study of calcipotriol and betamethasone valerate involving 345 patients with psoriasis vulgaris. ${ }^{46-50}$ Phototherapy with PUVA is associated with phototoxic reactions along with erythema, pruritis and epidermal dystrophy. ${ }^{49-51}$ Hepatic, 
renal, myelosuppressive, infectious and lipidemic disturbances, mild gastrointestinal intolerance and fatigue were observed in a retrospective review on systemic psoriatic therapy including 753 patients. ${ }^{52}$ Acitretin is the drug of choice for pustular and erythrodermic psoriasis. Teratogenicity, hepatitis, hyperlipidemia, pancreatitis, pseudotumorcerebri in addition to mucocutaneous side effects viz., cheilitis, skin peeling, alopecia were reported in patients treated with acitretin.

The immunosuppressants including methotrexate and cyclosporine were also reported with serious toxicities and significant adverse effects. ${ }^{33-55}$ The systemic biologic agents specifically target the components of immune system involved in the pathophysiology of psoriasis. TNF$\alpha$ inhibitors as in etanercept, infliximab and adalimumab or interleukin IL-12/23p40 inhibitors, ustekinumab are reported with incidences of tuberculosis reactivation and malignancy. 56

\section{Palmoplantar Psoriasis (Nonpustular)}

Psoriasis of palms and soles is an important condition for various reasons. Diagnosis is not always straight forward considering frequent clinical overlap with chronic eczema. To complicate this, there is frequent co-localization of these two conditions. Incidence of development of psoriasis over persistent chronic eczema due to Koebner's phenomena is not uncommon. Treatment of these two conditions will vary. Thus, proper diagnosis is essential for a successful outcome. Palmoplantar areas may be affected in pustular psoriasis. This may be extensive involving many areas of the body or it may specifically located over the palms and soles. Palmoplantar pustular psoriasis, however, is not discussed here. Only classical plaque-type palmoplantar psoriasis (PPP) is described here. PPP causes a significant psychological impact on the sufferer and hampers his/her daily activities. Management is difficult and more difficult than plaque psoriasis of nonpalmo-plantar areas. ${ }^{57}$

\section{Discussion on Evidence}

There is serious lack of evidence. Continuous activities and trauma might adversely affect this. Thus, protection from trauma and frequent emollient application is generally advocated (LOE 5).

\section{Topical treatment}

Topical treatment is always preferred as the first-line therapy, but more than two-third of the patients require systemic therapy. A randomized controlled trial (RCT) evaluated the comparative efficacy of topical $0.1 \%$ tazarotene cream and topical clobetasol propionate among 30 patients for 12 weeks. ${ }^{57}$ There was a good improvement in both without any significant difference between them. Complete clearance was noted among $52.9 \%$ and $61.5 \%$ of the patients, respectively, in tazarotene and clobetasol Group ${ }^{1}$ (LOE 2). Studies on other keratolytic agents such as salicylic acid are lacking. However, considering their safety and efficacy, many, including the author of this review, believe that these should be tried alone or in combination with other topicals such as topical corticosteroids (TCS) to reduce scaling (LOE 5).

Efficacy of calcipotriol has been reviewed. ${ }^{2}$ One randomized study among 39 patients reported that twice weekly topical calcipotriol under occlusion was as effective twice daily application without occlusion (LOE 2 ). One retrospective analysis reported 12 out of 60 patients $(20 \%)$ to have marked improvement with TCS while a similar extent of response was noticed among $17 \%$ ( $n=5$, total patients: 30 ) of patients who use only topical calcipotriol ${ }^{4}$ (LOE 4). ${ }^{58,59}$

Coal tar is another inexpensive agent and known to have some efficacy. Increased strength increases efficacy at the cost being increasingly cosmetically unacceptable. In a controlled trial, $6 \%$ crude coal tar was found to be better than salicylic acid and petroleum (both overnight, under occlusion). Coal tar resulted in good response among $76.5 \%$ of patients which was significantly higher than control group ${ }^{5}$ (LOE 3). ${ }^{60,61}$ One Cochrane review found one RCT that evaluated the comparative efficacy of narrowband ultraviolet $B$ (NB-UVB) and topical psoralenultraviolet A (PUVA). 62, 63 There was no significant difference in terms of clearance rate. Topical PUVA was found to effectively improve in $63 \%$ of cases in an uncontrolled study on 48 patients 7 (LOE 3). Topical PUVAsol (alternate day) was compared with topical clobetasol propionate cream and coal tar daily. In both groups, patients perceived "good improvement." Improvement or cure was noticed among 90\% versus $75 \%$ of palmar lesions and $76 \%$ versus $79 \%$ of plantar lesions, respectively, after TCS/tar and topical PUVAsol therapies. ${ }^{64}$

Broadband UVB (BB UVB) and paint PUVA (pPUVA) have been compared among 248 patients (124 ineach arm). pPUVA was found to have relatively higher efficacy. Complete remission was noticed among 36 (30\%) and 53 (42\%) and no response was found among 57 (47\%) and 14 (11\%) patients who were treated, respectively, with $B B$ UVB and pPUVA. ${ }^{65}$ PUVA and NB-UVB have some efficacy. Studies are sparse, and psoralens have known adverse effect. Thus, NB-UVB is better in high resource setting, and PUVAsol is better option as it is cheap and easily available everywhere. Topical PUVAsol and pPUVA are advantageous as oral psoralens are not needed. Considering all the available literature, topical PUVAsol or pPUVA appears preferable to PUVA and NB-UVB. Studies have shown the efficacy of excimer laser (308 $\mathrm{nm}$ ) in a case series ${ }^{10}$ (LOE 4). However, this is expensive and not available widely. ${ }^{66}$

\section{Systemic drugs}

A retrospective study evaluated the comparative efficacy of methotrexate (MTX) versus acitretin among 100 patients who had significant PPP. MTX was found to be significantly superior to acitretin after 12 weeks of therapy ${ }^{11}$ (LOE 4). However, its extent of response is generally less 
than in psoriasis vulgaris and often requires higher dose. In another study, MTX and acitretin were compared headto-head. High-dose MTX (28 mg/week) appears to be significantly superior to $35 \mathrm{mg} /$ day of acitretin ${ }^{12}$ (LOE 2). Only one retrospective study on cyclosporine (CyA) was found, in which only two patients were givenCyA. There was a marked response in both (100\%)[4] (LOE 4). ${ }^{67,68}$ Results of a pooled analysis on apremilast from three large, multicenter, randomized, placebo-controlled studies reported a complete clearance of lesions in $46 \%$ of the treated group at 16 th week ${ }^{13}$ ( LOE). ${ }^{69}$

Infliximab (5 mg/ $\mathrm{kg}$, every 4 weeks) has been tried in a placebo-controlled randomized pilot trial among 24 patients. This pilot study did not reach its primary end point of m-PPPASI 75 at week 14, but improvement was higher than placebo ${ }^{14}$ (LOE 2). ${ }^{70}$

One RCT and one open-label study had evaluated the efficacy of adalimumab in PPP. Efficacy was found in both the studies ${ }^{15}, 16$ (LOE 2). ${ }^{71,72}$ Ustekinumab was found to be moderately effective in an open-label study ${ }^{17}$ (LOE 3). ${ }^{73}$ Unpublished data from one randomized, double-blind, placebo-controlled trial (GESTURE study) evaluated secukinumab among a large number of patients with PPP. One-third of the patients who were on secukinumab 300 $\mathrm{mg}$ had clear or almost clear palms and soles at week 16. The result was higher than secukinumab $150 \mathrm{mg}$ and placebo. Overall, palmoplantar disease improved by more than $50 \%$ in patients on secukinumab $300 \mathrm{mg}$ at week $16 .^{74,75}$

However, a pooled analysis of a previously published RCT 18 on secukinumab in plaque-type psoriasis revealed that its efficacy in PPP was efficacious in comparison to placebo ${ }^{19}$ (LOE 2).

A single case report showed good response after combination therapy with etanercept and alitretinoin

${ }^{20}$ (LOE 4). More studies are necessary.

\section{Suggested Therapeutic Protocol}

Emollient is the first-line therapy and should be used as adjunctive to any other therapy. Topical keratolytics may be used as adjunctive therapy Overall, this is resistant to treatments. ${ }^{76}$ Suggestion for a therapeutic ladder is difficult. In addition to efficacy, selection of drugs will depend on safety profile as frequently long-term treatment is necessary Topical tazarotene, topical calcipotriol, and topical PUVAsol/pPUVA have been compared with potent TCS and were found to have slightly less efficacy (mostly statistically insignificant difference). They all can be considered as the first-line therapy. They are safer than potent TCS and can be used for longer duration Potent TCS may be preferred as the first-line therapy when faster response is required. However, safety data beyond 12 weeks are unknown and should be avoided Topical tazarotene, topical calcipotriol, and topical PUVAsol/pPUVA can also be considered as the first-line therapy. They are safer than potent TCS and can be used for longer duration and also be used after TCS as maintenance therapy Topical calcipotriol can be used under occlusion intermittently for faster response and higher efficacy and for avoiding daily therapy Topical coal tar is another option possibly of lesser efficacy than the above-mentioned first-line topical drugs. Higher available strength should be used. This can be considered as the second-line topical drug and may be tried before systemic drugs are used Phototherapy in the form of 308-nm UVB monochromatic excimer light is effective, possibly safe, but expensive. This can be used if facility is available MTX is the systemic drug of choice and is used when topical and phototherapies fail. However, higher dose is necessary Acitretin is less effective than MTX. This can be tried in cases that do not respond to MTX Apremilast and many biologics (many tumor necrosis factor inhibitors [TNFi] other than infliximab), secukinumab, and ustekinumab have shown variable efficacy. They can be used when standard therapies fail.

Table 1: Example of topical agent

\begin{tabular}{|c|c|c|c|c|c|c|}
\hline Name & Brand Name & Precautions & Side effects & Pregnancy & OTC/ Rx & Dose \\
\hline \multicolumn{7}{|c|}{ Corticosteroid } \\
\hline Clobetasol & $\begin{array}{l}\text { Clobex } \\
\text { Clormax }\end{array}$ & $\begin{array}{l}\text { Check with your } \\
\text { Dr. , if you have } \\
\text { skin rash, burning, } \\
\text { swelling, or } \\
\text { irritation on the } \\
\text { skin. } \\
\text { Blood and urine } \\
\text { test may be } \\
\text { needed to check } \\
\text { unwanted effects }\end{array}$ & $\begin{array}{l}\text { Burning, itching, } \\
\text { swelling, irritation } \\
\text { of treated skin. } \\
\text { Dry skin, hair loss, } \\
\text { redness } \\
\text { Avoid during } \\
\text { pregnancy. }\end{array}$ & $\mathrm{Rx}$ & $\begin{array}{l}\text { Cream } \\
\text { administer } \\
\text { up to } 4 \\
\text { weeks. }\end{array}$ & \\
\hline Triamcinolone & $\begin{array}{c}\text { AristocortA } \\
\text { Cinolar } \\
\text { Trinex }\end{array}$ & $\begin{array}{l}\text { Call dr if skin rash, } \\
\text { trouble in } \\
\text { breathing, and } \\
\text { swallowing. }\end{array}$ & $\begin{array}{l}\text { Change in skin } \\
\text { colour, unwanted } \\
\text { hair growth, tiny } \\
\text { red bumps, rash } \\
\text { around mouth. }\end{array}$ & $\begin{array}{l}\text { Avoid } \\
\text { during } \\
\text { pregnancy. }\end{array}$ & $\mathrm{Rx}$ & $\begin{array}{c}40-80 \mathrm{mg} \\
1 \mathrm{M} / \text { day } \\
\text { Gen. Dose } \\
25-100 \mathrm{mg} \\
1 \mathrm{M}\end{array}$ \\
\hline
\end{tabular}




\begin{tabular}{|c|c|c|c|c|c|c|}
\hline Fluocinolone & $\begin{array}{c}\text { Carpex } \\
\text { Derma } \\
\text { Smooth Fs }\end{array}$ & $\begin{array}{l}\text { It is not used in } \\
\text { sensitive areas } \\
\text { such asunderarm/ } \\
\text { face } \\
\text { Avoid the } \\
\text { wrapping areain } \\
\text { bandage or } \\
\text { wearing tight } \\
\text { clothing after } \\
\text { applying this } \\
\text { fliocinonide side } \\
\text { effect isincreases }\end{array}$ & $\begin{array}{l}\text { Changein skin color } \\
\text { Bruisingor shinyskin } \\
\text { Tiny red bumps or } \\
\text { rash around the } \\
\text { mouth. }\end{array}$ & $\begin{array}{c}\text { Avoid } \\
\text { during } \\
\text { pregnancy. }\end{array}$ & $\mathrm{Rx}$ & $\begin{array}{l}\text { Applied to } \\
\text { strength } \\
0.01 \% \text { - } \\
0.025 \%\end{array}$ \\
\hline Betamethasone & $\begin{array}{l}\text { Diprolene } \\
\text { Aphatrex } \\
\text { Diprosone }\end{array}$ & $\begin{array}{l}\text { Avoid Genital and } \\
\text { rectal areas and } \\
\text { skinareas, arm pit }\end{array}$ & $\begin{array}{l}\text { blood sugar level } \\
\text { more, frequent } \\
\text { urges tourinate, } \\
\text { Fellingsleepy, } \\
\text { thirsty and hungry, } \\
\text { Dizziness, weakness, } \\
\text { fatigue, and fast } \\
\text { heart beats. } \\
\text { Low potassium } \\
\text { level cause muscle } \\
\text { pain and cramp }\end{array}$ & $\begin{array}{l}\text { Risk of } \\
\text { preterm } \\
\text { birthwithin } \\
7 \text { days }\end{array}$ & $\mathrm{Rx}$ & $\begin{array}{c}0.6-7.2 \mathrm{mg} \\
\text { orally } \\
\text { twicedaily } \\
\text { or } 4 \text { times } \\
\text { daily } 0.6- \\
9 \mathrm{mg} / \text { day } \\
1 \mathrm{M}\end{array}$ \\
\hline
\end{tabular}

\begin{tabular}{|c|c|c|c|c|c|c|}
\hline Name & Brand Name & Precautions & Pregnancy & OTC/ Rx & Side effects & Dose \\
\hline \multicolumn{7}{|c|}{ Cream and ointment related to vitamin D } \\
\hline Vitamin D & $\begin{array}{l}\text { Calcipotriene } \\
\text { (Dovonex) is } \\
\text { a relative of } \\
\text { vitamin D-3. }\end{array}$ & $\begin{array}{l}\text { Individuals with the } \\
\text { following conditions } \\
\text { should not take } \\
\text { calcipotriene: } \\
\text { 1) Allergy to } \\
\text { calcipotrien cream. } \\
\text { 2)Elevated calcium } \\
\text { level in blood. } \\
\text { 3) Vitamin D toxicity. }\end{array}$ & $\begin{array}{c}\text { Avoid } \\
\text { during } \\
\text { pregnancy }\end{array}$ & OTC & $\begin{array}{l}\text { Do not use this } \\
\text { medicine on the } \\
\text { face, around the } \\
\text { eyes, or inside the } \\
\text { nose or mouth. Do } \\
\text { not use more than } \\
100 \text { grams per } \\
\text { week (one large } \\
\text { tube of cream or } \\
\text { ointment. }\end{array}$ & $\begin{array}{l}\text { In adult } 100 \\
\text { GM/week. } \\
\text { cream and } \\
\text { lotion for } \\
\text { Children 4-12 } \\
\text { years. } \\
\text { Infants safety } \\
\text { and efficacy not } \\
\text { established }\end{array}$ \\
\hline
\end{tabular}

\begin{tabular}{|c|c|c|c|c|c|c|}
\hline Name & Brand Name & Precautions & Pregnancy & $\begin{array}{c}\text { OTC/ } \\
\mathbf{R x}\end{array}$ & Side effects & Dose \\
\hline \multicolumn{7}{|c|}{ Tar containing preparations } \\
\hline $\begin{array}{c}\text { Tar } \\
\text { containing } \\
\text { preparations }\end{array}$ & $\begin{array}{c}\text { Coal tar (DHS } \\
\text { Tar, Doak Tar, } \\
\text { Theraplex T }\end{array}$ & $\begin{array}{l}\text { Individuals with the } \\
\text { following conditions } \\
\text { should not use tar- } \\
\text { containing preparations: } \\
\text { Tar allergy, Severe } \\
\text { inflammation, including } \\
\text { pustular psoriasis, } \\
\text { Patches of psoriasis. }\end{array}$ & $\begin{array}{l}\text { Avoid during } \\
\text { pregnancy }\end{array}$ & OTC & $\begin{array}{l}\text { Avoid contact with } \\
\text { eyes, inside the nose } \\
\text { or mouth, or open } \\
\text { wounds. }\end{array}$ & $\begin{array}{l}\text { Cream- } \\
\text { lotion } \\
\text { Apply 1-3 } \\
\text { times } \\
\text { daily. }\end{array}$ \\
\hline \multicolumn{7}{|c|}{ Tree bark extract } \\
\hline $\begin{array}{l}\text { Tree bark } \\
\text { extract }\end{array}$ & $\begin{array}{c}\text { Anthralin } \\
\text { (Dithranol, } \\
\text { Anthra-Derm, } \\
\text { Drithocreme) }\end{array}$ & $\begin{array}{l}\text { Do not use in individuals } \\
\text { with anthralin allergy }\end{array}$ & $\begin{array}{l}\text { Use with } \\
\text { caution }\end{array}$ & Rx & $\begin{array}{l}\text { Anthralin may cause } \\
\text { skin discoloration } \\
\text { (increased pigment) } \\
\text { and may burn or } \\
\text { irritate skin. Do not } \\
\text { use on the face, neck, } \\
\text { skin fold. }\end{array}$ & $\begin{array}{l}\text { Creams 1- } \\
2 \text { times a } \\
\text { daily. }\end{array}$ \\
\hline
\end{tabular}


Table 2: Examples of Systemic Agent

\begin{tabular}{|c|c|c|c|c|c|c|}
\hline \multicolumn{7}{|c|}{ Systemic Therapy } \\
\hline Name & Brand name & Precaution & Pregnancy & $\begin{array}{c}\text { OTC/ } \\
\mathbf{R x}\end{array}$ & Side effects & Dose \\
\hline Methotrexate & $\begin{array}{l}\text { Folitrax, } \\
\text { Oncotrex, } \\
\text { Rheumatrex }\end{array}$ & $\begin{array}{l}\text { This medicine may } \\
\text { cause serious allergic } \\
\text { reactions, including } \\
\text { anaphylaxis, which } \\
\text { may be life threatening } \\
\text { and require immediate } \\
\text { medical attention. } \\
\text { Check with your doctor } \\
\text { right away if you have } \\
\text { a rash, itching, } \\
\text { dizziness, fainting, fast } \\
\text { heartbeat, trouble } \\
\text { breathing or } \\
\text { swallowing, or chest } \\
\text { tightness while you are } \\
\text { using this medicine. }\end{array}$ & $\begin{array}{l}\text { Methotrexate can } \\
\text { stay in your body for } \\
\text { some time, so you } \\
\text { need to stop taking } \\
\text { methotrexate at least } \\
6 \text { months before } \\
\text { trying for a baby }\end{array}$ & $\mathrm{Rx}$ & $\begin{array}{l}\text { mouth sores, } \\
\text { diarrhoea, signs of } \\
\text { anaemia (such as } \\
\text { unusual tiredness, } \\
\text { pale skin), signs of } \\
\text { liver problems (such } \\
\text { as dark urine, } \\
\text { persistent nausea/ } \\
\text { vomiting, stomach/ } \\
\text { abdominal pain, } \\
\text { yellowing eyes/skin), } \\
\text { easy } \\
\text { bruising/bleeding, } \\
\text { black stools, enlarged } \\
\text { glands/lymph nodes, } \\
\text { bone pain, unusual } \\
\text { pain and discoloration } \\
\text { of the skin, signs of } \\
\text { kidney problems (such } \\
\text { as change in the } \\
\text { amount of urine), dry } \\
\text { cough, muscle } \\
\text { weakness }\end{array}$ & $\begin{array}{l}\text { Children under } 1 \\
\text { year: } 6 \text { mg } \\
\text { intrathecally (IT) } \\
\text { every 2-5 days } \\
\text { Children 1-2 years: } \\
8 \text { mg IT every 2-5 } \\
\text { days Children 2-3 } \\
\text { years: } 10 \text { mg IT } \\
\text { every 2-5 days } \\
\text { Children } 3 \text { years } \\
\text { and older: } 12 \text { mg } \\
\text { IT every 2- } \\
5 \text { days }\end{array}$ \\
\hline Acitretin & Soriatane & $\begin{array}{l}\text { Acitretin is in a } \\
\text { capsule. It is usually } \\
\text { taken once a day by } \\
\text { mouth with food. } \\
\text { Therapy is continued } \\
\text { until plaques have } \\
\text { decreased }\end{array}$ & $\begin{array}{l}\text { Acitretin may cause } \\
\text { serious deformity } \\
\text { and harm to an } \\
\text { unborn child } \\
\text { therefore it must } \\
\text { never be taken } \\
\text { during pregnancy. } \\
\text { Furthermore, women } \\
\text { should avoid } \\
\text { pregnancy for at } \\
\text { least three years } \\
\text { after stopping } \\
\text { acitretin. }\end{array}$ & $\mathrm{Rx}$ & $\begin{array}{l}\text { chapped lips peeling } \\
\text { fingertips, palms, and } \\
\text { soles of the feet } \\
\text { itching scaly skin all } \\
\text { over your } \\
\text { body weak nails sticky } \\
\text { or fragile skin runny } \\
\text { or dry nose, dry } \\
\text { mouth joint pain tight } \\
\text { muscles hair loss dry } \\
\text { eyes high cholesterol. }\end{array}$ & $\begin{array}{c}\text { Dosage Forms \& } \\
\text { Strengths capsule } \\
10 \mathrm{mg} \\
25 \mathrm{mg} \\
\text { Psoriasis } \\
25-50 \mathrm{mg} \text { PO qDay }\end{array}$ \\
\hline Cyclosporine & $\begin{array}{c}\text { Gen graph, } \\
\text { Neoral, } \\
\text { sandalMMUNE }\end{array}$ & $\begin{array}{l}\text { Avoid drinking } \\
\text { grapefruit juice or } \\
\text { eating grapefruit while } \\
\text { taking cyclosporine or } \\
\text { cyclosporine } \\
\text { (modified). Your } \\
\text { doctor may tell you to } \\
\text { limit the amount of } \\
\text { potassium in your diet. }\end{array}$ & $\begin{array}{l}\text { Cyclosporine (CsA) } \\
\text { therapy must often } \\
\text { be continued during } \\
\text { pregnancy to } \\
\text { maintain maternal } \\
\text { health in such } \\
\text { conditions as organ } \\
\text { transplantation and } \\
\text { autoimmune disease. }\end{array}$ & $\mathrm{Rx}$ & $\begin{array}{l}\text { Shaking (tremor) } \\
\text { Kidney damage. High } \\
\text { blood pressure } \\
\text { (hypertension) } \\
\text { Infection. } \\
\text { Headache. } \\
\text { Nausea. } \\
\text { Male-pattern hair } \\
\text { growth in women. } \\
\text { Excessive hair growth. }\end{array}$ & $\begin{array}{c}\text { Oral } \\
\text { 4-12 hours } \\
\text { pretransplant: } 15 \\
\text { mg/kg orally for } 1 \\
\text { dose } \\
\text { 1-2 weeks } \\
\text { posttransplant: } 15 \\
\text { mg/kg/day orally } \\
\text { divided twice daily } \\
\text { Reduce 5\% per } \\
\text { week until: 5-10 } \\
\text { mg/kg/day orally } \\
\text { divided twice daily } \\
\text { Intravenous (IV) } 4- \\
\text { 12 hours } \\
\text { pretransplant IV: } \\
5-6 \text { mg/kg IV for } 1 \\
\text { dose over } 2-6 \\
\text { hours Post- } \\
\text { transplant, until } \\
\text { can tolerate oral } \\
\text { therapy: 5-6 } \\
\text { mg/kg IV once/day }\end{array}$ \\
\hline
\end{tabular}




\begin{tabular}{|c|c|c|c|c|c|c|}
\hline \multicolumn{7}{|c|}{ Biological Agents } \\
\hline Name & Brand name & Precaution & Pregnancy & $\begin{array}{c}\text { OTC/ } \\
\text { Rx }\end{array}$ & Side effects & Dose \\
\hline Adalimumab & $\begin{array}{l}\text { Humira, Hulio, } \\
\text { Amjevita }\end{array}$ & $\begin{array}{l}\text { Check with your doctor } \\
\text { right away if you or } \\
\text { your child think you } \\
\text { are getting an infection } \\
\text { or if you get a fever or } \\
\text { chills, cough or } \\
\text { hoarseness, lower back } \\
\text { or side pain, or painful } \\
\text { or difficult urination. } \\
\text { Check with your doctor } \\
\text { right away if you or } \\
\text { your child notice any } \\
\text { unusual bleeding or } \\
\text { bruising, black, tarry } \\
\text { stools, blood in the } \\
\text { urine or stools, or } \\
\text { pinpoint red spots on } \\
\text { your skin. } \\
\text { Be careful when using } \\
\text { a regular toothbrush, } \\
\text { dental floss, or } \\
\text { toothpick. Your } \\
\text { medical doctor, } \\
\text { dentist, or nurse may } \\
\text { recommend other } \\
\text { ways to clean your } \\
\text { teeth and gums. Check } \\
\text { with your medical } \\
\text { doctor before having } \\
\text { any dental work done. }\end{array}$ & $\begin{array}{l}\text { Adalimumab } \\
\text { exposure in } \\
\text { pregnancy compared } \\
\text { to diseased } \\
\text { unexposed } \\
\text { pregnancies was not } \\
\text { associated with an } \\
\text { increased risk for any } \\
\text { of the adverse } \\
\text { outcomes examined }\end{array}$ & $\mathrm{Rx}$ & $\begin{array}{l}\text { pain, swelling, } \\
\text { redness or itchy skin } \\
\text { where your injection } \\
\text { was given. a mild } \\
\text { nose, throat or sinus } \\
\text { infection. a headache. } \\
\text { stomach pains, feeling } \\
\text { or being sick. a rash }\end{array}$ & $\begin{array}{c}\text { Dosage Forms \& } \\
\text { Strengths } \\
\text { injection, prefilled } \\
\text { glass syringe } \\
10 \mathrm{mg} / 0.1 \mathrm{~mL} \\
\text { (Humira) } \\
10 \mathrm{mg} / 0.2 \mathrm{~mL} \\
\text { (Humira, Abrilada) } \\
20 \mathrm{mg} / 0.2 \mathrm{~mL} \\
\text { (Humira) } \\
20 \mathrm{mg} / 0.4 \mathrm{~mL} \\
\text { (Humira, Amjevita } \\
\text {, } \\
\text { Cyltezo, Abrilada) } \\
40 \mathrm{mg} / 0.4 \mathrm{~mL} \\
\text { (Humira) } \\
40 \mathrm{mg} / 0.8 \mathrm{~mL} \\
\text { (Humira, Cyltezo, } \\
\text { Amjevita, Hadlima, } \\
\text { Hyrimoz, Abrilada) }\end{array}$ \\
\hline Entarnercept & $\begin{array}{c}\text { Intacept, } \\
\text { Etacept } \\
\text { Enbral }\end{array}$ & $\begin{array}{l}\text { While you are being } \\
\text { treated with } \\
\text { etanercept, do not } \\
\text { have any } \\
\text { immunizations } \\
\text { (vaccines) without } \\
\text { your doctor's approval } \\
\text { This medicine may } \\
\text { cause serious allergic } \\
\text { reactions including } \\
\text { anaphylaxis. This can } \\
\text { be lifethreatening and } \\
\text { requires immediate } \\
\text { medical attention. } \\
\text { Check with your doctor } \\
\text { right away if you or } \\
\text { your child have a rash, } \\
\text { itching, hoarseness, } \\
\text { trouble breathing, } \\
\text { trouble swallowing, or } \\
\text { any swelling of your } \\
\text { hands, face, or mouth } \\
\text { after you receive the } \\
\text { medicine. }\end{array}$ & $\begin{array}{l}\text { They do not increase } \\
\text { the risk for } \\
\text { miscarriages or } \\
\text { congenital } \\
\text { malformations and } \\
\text { therefore, appear } \\
\text { reasonably safe if } \\
\text { used during the first } \\
\text { half of pregnancy. }\end{array}$ & $\mathrm{Rx}$ & $\begin{array}{l}\text { blocked or runny } \\
\text { nose. a sore throat. } \\
\text { feeling sick or } \\
\text { vomiting. } \\
\text { a mild fever. } \\
\text { headaches. dizziness, } \\
\text { stomach pain , rash. }\end{array}$ & $\begin{array}{c}\text { Dosage Forms \& } \\
\text { Strengths injection } \\
\text { solution, prefilled } \\
\text { syringe } \\
25 \mathrm{mg} / 0.5 \mathrm{~mL} \\
\text { (Enbrel, Erelzi, } \\
\text { Eticov) } 50 \mathrm{mg} / \mathrm{mL} \\
\text { (Enbrel, } \\
\text { Erelzi, Eticovo) } \\
\text { injection solution, } \\
\text { prefilled } \\
\text { autoinjector } \\
50 \mathrm{mg} / \mathrm{mL} \text { (Enbrel, } \\
\text { Erelzi) injection, } \\
\text { lyophilized powder } \\
\text { for reconstitution }\end{array}$ \\
\hline Infliximab & $\begin{array}{c}\text { Remicade, } \\
\text { Inflectra, Avsola }\end{array}$ & $\begin{array}{l}\text { It is important to have } \\
\text { your heart checked } \\
\text { closely if you receive } \\
\text { infliximab. Call your } \\
\text { doctor right away if } \\
\text { you have trouble } \\
\text { breathing, swelling in } \\
\text { the ankles and feet, or } \\
\text { a sudden weight gain. } \\
\text { Do not take other } \\
\text { medicines unless they } \\
\text { have been discussed } \\
\text { with your doctor. }\end{array}$ & $\begin{array}{l}\text { Risky or Avoiding } \\
\text { during pregnancy. }\end{array}$ & $\mathrm{Rx}$ & $\begin{array}{l}\text { Common side } \\
\text { effects include a } \\
\text { blocked or runny } \\
\text { nose, headaches, } \\
\text { dizziness, flushing, a } \\
\text { rash, stomach pain, } \\
\text { indigestion or feeling } \\
\text { sick. }\end{array}$ & $\begin{array}{c}\text { Infants and } \\
\text { children } 6 \text { months } \\
\text { old or younger: } \\
0.27 \mathrm{mg} / \mathrm{day} \\
7 \text { months old to } 1 \\
\text { year old: } 11 \\
\mathrm{mg} / \text { day } \\
\text { ages } 1 \text { to } 3 \text { years } \\
\text { old: } 7 \mathrm{mg} / \text { day ages } \\
4 \text { to } 8 \text { years old: } 10 \\
\text { mg/day ages } 9 \text { to } \\
12 \text { years old: } 8 \\
\text { mg/day Males } \\
\text { (teens and adults) }\end{array}$ \\
\hline
\end{tabular}




\begin{tabular}{|c|c|c|c|c|c|c|}
\hline & & & & & & $\begin{array}{c}\text { age } 13 \text { years old: } 8 \\
\mathrm{mg} / \text { day } \\
\text { ages } 14 \text { to } 18 \text { years } \\
\text { old: } 11 \mathrm{mg} / \text { day } \\
\text { ages } 19 \text { years old } \\
\text { or older : } 8 \mathrm{mg} / \text { day } \\
\text { Females (teens } \\
\text { and adults) } \\
\text { age } 13 \text { years old: } 8 \\
\text { mg/day ages } 14 \text { to } \\
18 \text { years old: } 15 \\
\text { mg/day }\end{array}$ \\
\hline Certolizumub & Cimiza & $\begin{array}{l}\text { It is very important } \\
\text { that your doctor check } \\
\text { your progress at } \\
\text { regular visits to make } \\
\text { sure that this medicine } \\
\text { is working } \\
\text { properly.Blood and } \\
\text { urine tests may be } \\
\text { needed to check for } \\
\text { unwanted } \\
\text { effects.Certolizumab } \\
\text { can temporarily lower } \\
\text { the number of white } \\
\text { blood cells in your } \\
\text { blood, increasing the } \\
\text { chance of getting an } \\
\text { infection. It can also } \\
\text { lower the number of } \\
\text { platelets, which are } \\
\text { necessary for proper } \\
\text { blood clotting. }\end{array}$ & $\begin{array}{l}\text { Risky during } \\
\text { pregnancy }\end{array}$ & $\mathrm{Rx}$ & $\begin{array}{l}\text { Bladder pain bloody } \\
\text { or cloudy urine } \\
\text { body aches or pain, } \\
\text { chills, cough difficult, } \\
\text { burning, or painful } \\
\text { urination difficulty } \\
\text { with breathing, ear } \\
\text { congestion } \\
\text { fever. frequent urge } \\
\text { to urinate headache } \\
\text { hoarseness loss of } \\
\text { voice lower back or } \\
\text { side pain. }\end{array}$ & $\begin{array}{l}\text { For ankylosing } \\
\text { spondylitis: } \\
\text { Adults - At first, } \\
400 \text { milligrams } \\
\text { (mg) given as } 2 \\
\text { doses of } 200 \mathrm{mg} \\
\text { injected under the } \\
\text { skin. This dose is } \\
\text { repeated after } 2 \\
\text { weeks and } 4 \\
\text { weeks. Your doctor } \\
\text { may continue the } \\
\text { dose as } 200 \mathrm{mg} \\
\text { every } 2 \text { weeks or } \\
400 \text { mg every } 4 \\
\text { weeks. }\end{array}$ \\
\hline \multicolumn{7}{|c|}{ Newer Agent } \\
\hline Apremilast & Aprezo & $\begin{array}{l}\text { Apremilast may cause } \\
\text { severe diarrhea, } \\
\text { nausea, or vomiting } \\
\text { which is more likely in } \\
\text { patients } 65 \text { years of } \\
\text { age or older, or in } \\
\text { patients with low } \\
\text { blood pressure } \\
\text { (hypotension) or low } \\
\text { blood volume } \\
\text { (hypovolemia). Talk to } \\
\text { your doctor if you have } \\
\text { concerns }\end{array}$ & $\begin{array}{l}\text { Risky in pregnancy or } \\
\text { miscarriage occur } \\
\text { after exposure }\end{array}$ & $\mathrm{Rx}$ & $\begin{array}{l}\text { diarrhea. nausea. } \\
\text { stomach pain. } \\
\text { vomiting. headache. } \\
\text { sore throat, cough, } \\
\text { and fever. sneezing, } \\
\text { runny nose, and nasal } \\
\text { congestion }\end{array}$ & $\begin{array}{l}\text { The recommended } \\
\text { dose of apremilast } \\
\text { is } 30 \mathrm{mg} \text { taken } \\
\text { orally twice daily, } \\
\text { approximately } 12 \\
\text { hours apart } \\
\text { (morning and } \\
\text { evening), with no } \\
\text { food restrictions }\end{array}$ \\
\hline
\end{tabular}

Table no 3: Combination therapy of biologic agents

\begin{tabular}{|c|c|c|c|c|}
\hline & Name & Dosing & CombinationTreatment & Response \\
\hline \multirow[t]{3}{*}{$\begin{array}{l}\text { TNF alpha } \\
\text { inhibitor }\end{array}$} & $\begin{array}{c}\text { Etanercept } \\
\text { (enbrel) }\end{array}$ & $\begin{array}{c}\text { S.C. Inj } \\
\text { Start : } 50 \mathrm{mg} \text { twice } \\
\text { per week for } 12 \text { months } \\
\text { Maintenance: } \\
\text { 50mg per week }\end{array}$ & $\begin{array}{c}\text { Topical } \\
\text { acitretin } \\
\text { Methotrexate } \\
\text { Apremilast } \\
\text { Cyclosporine } \\
\text { Narrow band UVB }\end{array}$ & $\begin{array}{l}\text { Definitive a response :12-16 } \\
\text { weeks immunogenicity no } \\
\text { conclusive data on loss of } \\
\text { response due to antibodies but } \\
\text { demonstrated in small \% of patient }\end{array}$ \\
\hline & $\begin{array}{l}\text { Infliximab } \\
\text { (remicade) }\end{array}$ & $\begin{array}{c}\text { IV infusion } \\
\text { Start :5 mg/kg at } \\
\text { week } 026 \\
\text { maintenance:5- } \\
\text { 10mg/kg at least } \\
\text { every } 8 \text { weeks }\end{array}$ & $\begin{array}{l}\text { Topicals } \\
\text { Acitretin } \\
\text { methotrexate } \\
\text { apremilast }\end{array}$ & $\begin{array}{c}\text { Definitive a response :8-10 } \\
\text { weeks immunogenicity :high } \\
\text { risk for antibodies if infusion } \\
\text { interval is greater then } 8 \text { weeks } \\
\text { significant no. of patient lose response } \\
\text { addition of MXT may reduce } \\
\text { immunogenicity }\end{array}$ \\
\hline & $\begin{array}{c}\text { Adalimumab } \\
\text { (humira) }\end{array}$ & $\begin{array}{l}\text { S.C. injection } \\
\text { start: } 80 \mathrm{mg} \\
\text { followed by } 40\end{array}$ & $\begin{array}{c}\text { Topicals } \\
\text { acitretin } \\
\text { methotrexate }\end{array}$ & $\begin{array}{l}\text { Definitive a response:12-16 } \\
\text { weeks immunogenicity : risk } \\
\text { antibiotic that lower efficacy }\end{array}$ \\
\hline
\end{tabular}




\begin{tabular}{|c|c|c|c|c|}
\hline & & $\begin{array}{l}\text { mg } 1 \text { week later } \\
\text { maintenance :40 } \\
\text { mg every } 2 \text { weeks }\end{array}$ & $\begin{array}{c}\text { apremilast } \\
\text { cyclosporine } \\
\text { narrow band UVB }\end{array}$ & $\begin{array}{l}\text { addition of MXT may reduce } \\
\text { immunogenicity }\end{array}$ \\
\hline & $\begin{array}{c}\text { Certolizumab } \\
\text { (cimzia) }\end{array}$ & $\begin{array}{l}\text { S.C. injection } \\
\text { start: } 400 \text { mg split } \\
\text { into } 2 \text { inj. Every } \\
\text { other weeks } \\
\text { Maintenance: } 200 \text { or } 400 \\
\text { mg every week }\end{array}$ & $\begin{array}{l}\text { No evidence } \\
\text { available on } \\
\text { combination } \\
\text { therapy but } \\
\text { most likely similar } \\
\text { characteristics as other } \\
\text { TNF inhibitor }\end{array}$ & $\begin{array}{l}\text { Definitive response :12-16 } \\
\text { weeks immunogenicity :no } \\
\text { evidence but most likely } \\
\text { similar to other TNF inhibitor }\end{array}$ \\
\hline $\begin{array}{l}\text { IL-12/IL- } \\
23 \\
\text { inhibitor }\end{array}$ & $\begin{array}{c}\text { Ustekinumab } \\
\text { (STELARA) }\end{array}$ & $\begin{array}{c}\text { IV infusion } \\
\text { start: } 45 \mathrm{mg} \text { at week } 0 \text { and } \\
4 \text { for patient weight more } \\
\text { then } 100 \mathrm{~kg} \\
\text { maintenance: } 45 \mathrm{mg} \text { every } \\
12 \text { weeks for patient } \\
\text { weighing } 100 \mathrm{~kg} \text { or less } 90 \\
\text { mg every } 4 \text { weeks for } \\
\text { patient weighing } \\
\text { more than } 100 \mathrm{~kg}\end{array}$ & $\begin{array}{l}\text { Topical } \\
\text { acitretin } \\
\text { methotrexate } \\
\text { apremilast } \\
\text { cyclosporine } \\
\text { narrow band } \\
\text { UVB }\end{array}$ & $\begin{array}{l}\text { Definitive response : } 12 \text { weeks of } \\
\text { continuous therapy } \\
\text { immunogenicity : some patient develop } \\
\text { antibodies addition of } \\
\text { MXT may reduce immunogenicity }\end{array}$ \\
\hline \multirow[t]{2}{*}{$\begin{array}{l}\text { IL-17 } \\
\text { inhibitor }\end{array}$} & $\begin{array}{l}\text { Secukinab } \\
\text { (cosentyx) }\end{array}$ & $\begin{array}{c}\text { S.C. injection } \\
\text { start: } 300 \mathrm{mg} \text { at } \\
\text { weeks } 0 \text { through } 4 \\
\text { then every } 4 \text { weeks } \\
\text { maintenance :300 } \\
\text { mg every } 4 \text { weeks } \\
\text { some patient } \\
\text { respond to } 150 \\
\text { mg }\end{array}$ & $\begin{array}{l}\text { No data } \\
\text { available on } \\
\text { combination } \\
\text { with other } \\
\text { therapies }\end{array}$ & $\begin{array}{l}\text { Definitive response : } 12 \text { weeks } \\
\text { after continuous therapy } \\
\text { immunogenicity : antibodies } \\
\text { rarely found and were not } \\
\text { associated with loss of response }\end{array}$ \\
\hline & $\begin{array}{l}\text { Ixekizumab } \\
\text { (taltz) }\end{array}$ & $\begin{array}{l}\text { S.C. injection } \\
\text { start:160 mg } \\
\text { followed by } 80 \\
\text { mg at weeks } 2,4 \text {, } \\
6,7,10 \text { and } 12 \\
\text { maintenance : } 80 \\
\text { mg every } 4 \text { weeks }\end{array}$ & $\begin{array}{l}\text { No data } \\
\text { available on } \\
\text { combination } \\
\text { with other } \\
\text { therapies }\end{array}$ & $\begin{array}{c}\text { Definitive response :12 weeks } \\
\text { after continuous therapy } \\
\text { immunogenicity :antibodies } \\
\text { demonstrated in some patient and } \\
\text { associated with reduced drug conc. and } \\
\text { loss efficacy }\end{array}$ \\
\hline \multirow[t]{2}{*}{$\begin{array}{l}\text { IL-23 } \\
\text { inhibitor }\end{array}$} & $\begin{array}{c}\text { Guselkumab } \\
\text { (tremfya) }\end{array}$ & $\begin{array}{c}\text { S.C. injection } \\
\text { start: } 100 \text { mg at } \\
\text { weeks } 0 \text { and } 4 \\
\text { maintenance: } 100 \\
\text { mg every } 8 \text { weeks }\end{array}$ & $\begin{array}{l}\text { No data } \\
\text { available on } \\
\text { combination } \\
\text { therapies }\end{array}$ & $\begin{array}{l}\text { Definitive response : } 12 \text { weeks } \\
\text { after continuous therapy } \\
\text { immunogenicity: antibodies } \\
\text { have been found but no } \\
\text { neutralizing antibodies detected }\end{array}$ \\
\hline & $\begin{array}{c}\text { Tidrakizumab } \\
\text { (iiumya) }\end{array}$ & $\begin{array}{l}\text { S.C.injection start: } 100 \text { or } \\
200 \mathrm{mg} \text { at weeks } 0 \text { and } 4 \\
\text { maintenance: } 100 \text { or } 200 \\
\text { mg every } 12 \text { weeks }\end{array}$ & $\begin{array}{l}\text { No data available on } \\
\text { combinationtherapies }\end{array}$ & $\begin{array}{l}\text { Definitive response : } 12 \text { weeksafter } \\
\text { continuous therapy immunogenicity: } \\
\text { antibodies found in some patient and } \\
\text { associated with loss of efficacy }\end{array}$ \\
\hline
\end{tabular}

\section{Combination therapy with Methotrexate}

\section{Efficacy and safety of cyclosporine versus methotrexate} in severe psoriasis.

The purpose of this study was to compare the efficacy and safety of daily cyclosporine with weekly methotrexate in the management of severe psoriasis. Thirty consecutive patients with severe psoriasis were randomly assigned to treatment with cyclosporine or methotrexate. The initial dose of cyclosporine was $3 \mathrm{mg} / \mathrm{kg} /$ day which was increased to a maximum of $4 \mathrm{mg} / \mathrm{kg}$ after two weeks of therapy when the response was not adequate. Methotrexate was administered weekly at a dose of 0.5 $\mathrm{mg} / \mathrm{kg}$. Clinical response was assessed by calculating PASI score in all patients at biweekly intervals. Patients were followed up fortnightly up to a maximum of 12 weeks. The doses of both drugs were gradually tapered once $>75 \%$ reduction in disease severity was attained. Marked improvement $(>75 \%)$ reduction in PASI was noted in all patients except for one in the cyclosporine. Patients on 
methotrexate were found to have more rapid and complete clearance than those on cyclosporine. Both drugs were well tolerated. Side effects in both the treatment groups were minor, transient, and manageable. At doses with comparable safety profiles, methotrexate resulted in more rapid and cost effective clearance of patients with severe psoriasis. Cyclosporine can provide an effective and safe alternative. ${ }^{77}$

\section{Methotrexate combination with JAK inhibitors}

Tofacitinib is the first Janus kinase (JAK) inhibitors approved at a dosage $5 \mathrm{mg}$ twice daily for the treatment of active psoriatic arthritis (PsA), where it is indicated in combination with methotrexate for patients who have had an inadequate response or who have been intolerant to a prior therapy with a disease modifying antirheumatic drug (DMARD). Two well designed phase III trials and patients with PsA after 3 months of treatment, while also improving skin psoriasis, enthesitis, dactylitis, physical function and fatigue. By comparing methotrexate monotherapy with methotrexate plus leflunomide combination therapy in psoriatic arthritis: protocol of a randomised placebo- controlled, double blind clinical trial. $^{78}$

\section{Methotrexate and combination with DMARDS for the treatment of severe psoriasis}

There are several DMARD's which are used as the monotherapy in Psoriasis arthritis such as entnercept, infliximab, adalimumab etc are very much effective alone as well. When give in combination with methotrexate the efficacy of the DMARD's which causes increase in the lifestyle of the patients and causes improvement in psoriasis. $^{79}$

\section{CONCLUSION}

Psoriasis is a complex multifactorial disease for which various novel therapies have arisen in the past years. In spite of the refinement of the targeted therapies, psoriasis remains a treatable but so far not curable disease. The targeted therapies show high clinical efficacy for the inhibition of IL-23 and IL-17. Some degree of a persistent antipsoriatic effect by these therapies could be demonstrated after drug discontinuation and argue for disease modification concept. This important finding will be followed up in ongoing and future studies.

From this above patient survey, we found that the maximum number of peoples suffering from psoriasis was above 40 years \& also it was found that more number of females patients are suffering from psoriasis. People suffering with psoriasis was undergoing with allopathic treatment.

From pharmacy survey we had looked for medication of both allopathic as well as ayurvedic in the market \& studied the market segment on the basis of which formulation has been prescribed by physician, so we found that allopathic treatment has been prescribed by doctor.
From physician survey we found that Plaque psoriasis was most common in patient $\&$ also from this survey we found that biologic therapy was most costly than other therapies. From physician survey we found that combination therapy are used to treat severe psoriasis and incase of mild psoriasis topical or systemic therapy prescribed by physician.

From the above study of psoriasis, we come to the conclusion that, the treatment methods and drugs available in the market, most of them gives symptomatic relief or are effective towards only one of the cause of Psoriasis which fails in treating psoriasis. The combination therapies are used nowadays for treating psoriasis, but if this combination is multitargeted treating multiple causes then it might be useful for chronic psoriasis treatment.

\section{REFERENCES}

1. Kumari T, Gupta P. Role of different natural products in the management of psoriasis. Journal of Emerging Technologies and Innovative Research (JETIR) 2021; 8(1): 135-6.

2. Christophers, E. Psoriasis-Epidemiology and clinical Exp spectrum. Clin. Exp. Dermatol. 2001; 26(4): 314-320.doi: 10.1046/j.1365-2230.2001.00832.x;PMID: 11422182.

3. Parisi R, Symmons D.P, Griffiths C.E, Ashcroft D.M, Global epidemiology of psoriasis: A systematic review of incidence and prevalence. J. Investig.Dermatol.2013; 133(2): 377-385.doi: 10.1038/jid.2012.339; PMID: 23014338.

4. Ogava $E$, Sato $Y$, Akane $M$, Ryuheri O. Pathogenesis of psoriasis and development of treatment. The Journal Of Dermatology 2018; 45(3): 264-272 .doi: 10.1111/1346-8138.14139;PMID: 29226422.

5. Rendon A, Schakel K. Psoriasis Pathogenesis and Treatment. International Journal of molecular sciences 2019; 20: 1475.doi:10.3390/ijms20061475

6. Ortonne, J, Chimenti S, Luger, T, Puig, L, Reid F, Trueb R.M. Scalp psoriasis: European consensus on grading and treatment algorithm. J. Eur. Acad. Dermatol. Venereol. 2009; 23(12): 14351444. doi: 10.1111/j.1468-3083.2009.03372.x. Epub 2009 Jul 15; PMID: 19614856.

7. Nestle, F.O.; Kaplan, D.H.; Barker, J. Psoriasis. N. Engl. J. Med. 2009; 361(5): 496-509. doi: 10.1056/NEJMra0804595. PMID: 19641206

8. Ko, H.C.; Jwa, S.W.; Song, M.; Kim, M.B.; Kwon, K.S. Clinical course of guttate psoriasis: Long-term follow-up study. J. Dermatol. 2010; 37(10): 894-899. doi: 10.1111/j.13468138.2010.00871.x;PMID: 20860740.

9. Martin, .A.; Chalmers, R.J.; Telfer, N.R. How great is the risk of further psoriasis following a single episode of acute guttate psoriasis? Arch. Dermatol.1996; 132(6): 717-718. doi: 10.1001/archderm.1996.03890300147032;PMID: 8651734.

10. Navarini, A.A.; Burden, A.D.; Capon, F.; Mrowietz, U.; Puig, L.; Koks, S.; Kingo, K.; Smith, C.; Barker, J.N.; Network, E. European consensus statement on phenotypes of pustular psoriasis. J. Eur. Acad. Dermatol. Venereol. 2017; 31(11): 1792-1799.doi: 10.1111/jdv.14386. Epub 2017 Aug 29;PMID: 28585342.

11. Pasch, M.C. Nail psoriasis: A review of treatment options. Drugs. 2016; 76(6): 675-705doi: 10.1007/s40265-016-0564-5; PMID: $27041288 ;$ PMCID: PMC4833799.

12. Villani, A.P.; Rouzaud, M.; Sevrain, M.; Barnetche, T.; Paul, C.; Richard, M.A.; Beylot-Barry, M.; Misery, L.; Joly, P.; Le Maitre, M.; et al. Prevalence of undiagnosed psoriatic arthritis among psoriasis patients: Systematic review and meta-analysis. J. Am. 
Acad. Dermatol. 2015; 73(2): 242-248.doi: 10.1016/j.jaad.2015.05.001. Epub 2015 Jun 6; PMID: 26054432.

13. Schadler ED, Ortel B, Mehlis SL. Biologics for the primary care physician: Review and treatment of psoriasis. Dis Mon 2019; 65(3): 51-90.doi: 10.1016/j.disamonth.2018.06.001. Epub 2018 Jul 20; PMID: 30037762.

14. Tagami H. Triggering factors. Clin Dermatol 1997; 15(5): 67785.doi: 10.1016/s0738-081x(97)00024-2; PMID: 9313966.

15. Baker BS, Swain AF, Fry L, Valdimarsson H. Epidermal T lymphocytes and HLA-DR expression in psoriasis. Br J Dermatol 1984; 110(5): 555-64.doi: 10.1111/j.1365-2133.1984.tb04678.x;PMID: 6232938.

16. 16) Shibata $S$, Saeki $H$, Tada $Y$, Karakawa $M$, Komine $M$, Tamaki K. Serum high molecular weight adiponectin levels are decreased in psoriasis patients. J Dermatol Sci 2009; 55(1): 623.doi:10.1016/j.jdermsci.2009.02.009. Epub 2009 Apr 22;PMID: 19395243.

17. Kumar S, Han J, Li T, Qureshi AA, Choi HK, Qureshi AA. Obesity, waist circumference, weight change and the risk of psoriasis in US women. J Eur Acad Dermatol Venereol 2013; 27(10): 12938.doi:10.1111/jdv.12001;PMID:23057623.

18. Abel EA, DiCicco LM, Orenberg EK, Fraki JE, Farber EM. Drugs in exacerbation of psoriasis. J Am Acad Dermatol 1986; 15(5 Pt 1): 1007-22. doi: 10.1016/s0190-9622(86)70265-x;PMID: 2878015

19. Sondergaard J, Wadskov S, Jensen HA, Mikkelsen HI. Aggravation of psoriasis and occurrence of psoriasiform cutaneous eruptions in duced by practolol (Eraldin). Acta Derm Venereol 1976; 56(3): 239-43.PMID: 59510.

20. Seville RH. Psoriasis and stress. Br J Dermatol 1977; 97(3): 297302.doi:10.1111/j.1365-2133.1977.tb15186.x;PMID: 921900.

21. Zhou C, Yu X, Cai D, Liu C, Li C. Role of corticotropin-releasing hormone and receptor in the pathogenesis of psoriasis. Med Hypotheses 2009; 73(4): 513-5; doi: 10.1016/j.mehy.2009.02.051. Epub 2009 Jun 26; PMID: 19560286.

22. Mills $C M$, Srivastava ED, Harvey IM, et al. Smoking habits in psoriasis: a case control study. Br J Dermatol 1992; 127(1): 18-21; doi: 10.1111/j.1365-2133.1992.tb14818.x;PMID: 1637689.

23. Henseler T. The genetics of psoriasis. J Am Acad Dermatol 1997; 37(2 Pt 3): S1-S11.PMID: 9270550.

24. Dunna SF, Finlay AY. Psoriasis: improvement during and worsening after pregnancy. Br J Dermatol 1989; 120(4): 584 4;doi: 10.1111/j.1365-2133.1989.tb01338.x. PMID: 2730848.

25. Infante-Duarte C, Horton HF, Byrne MC, Kamradt T. Microbial lipopeptides induce the production of IL-17 in Th cells. J Immunol 2000; 165: 6107-6115.

26. Fossiez F. T cell interleukin-17 induces stromal cells to produce proinflammatory and hematopoietic cytokines. J Exp Med 1996; 183: https://doi.org/10.4049/jimmunol.165.11.6107 2593-2603.DOI:

27. Lowes MA, Suarez-Farinas M, Krueger JG. Immunology of psoriasis. Annu Rev Immunol 2014; 32: 227-255;doi: 10.1146/annurev-immunol-032713-120225. PMID: 24655295.

28. Lowes MA, Chamian F, Abello MV et al. Increase in TNF-alpha and inducible nitric oxide synthase-expressing dendritic cells in psoriasis and reduction with efalizumab (anti-CD11a). Proc Natl Acad Sci USA 2005; 102: 19057-19062; doi: 10.1073/pnas.0509736102. PMID: 16380428.

29. Wilsmann-Theis D, Koch $S$, Mindnich $C$ et al. Generation and functional analysis of human TNF-a/iNOS-producing dendritic cells(Tip-DC). Allergy 2013; 68: 890-898.doi: 10.1111/all.12172. Epub 2013 Jun 6. PMID: 23742057.
30. Jacobs MD, Harrison SC. Structure of an IkappaBalpha/NF-kappaB complex. Cell 1998; 95: 749-758.doi: 10.1016/s00928674(00)81698-0. PMID: 9865693

31. Ghosh S, Baltimore D. Activation in vitro of NF-kappa B by phosphorylation of its inhibitor I kappa B. Nature 1990; 344: 678682. doi: 10.1038/344678a0. PMID: 2157987.

32. Tsuruta D. NF-kappaB links keratinocytes and lymphocytes in the pathogenesis of psoriasis. Recent Pat Inflamm Allergy Drug Discov 2009; 3: 40-48.doi: 10.2174/187221309787158399. PMID: 19149745.

33. Andres, R.M.; Hald, A.; Johansen, C.; Kragballe, K.; Iversen, L. Studies of jak/stat3 expression and signalling in psoriasis identifies STAT3-SER727 phosphorylation as a modulator of transcriptional activity. Exp. Dermatol. 2013; 22: 323-328. doi: 10.1111/exd.12128. PMID: 23614738.

34. Nestle, F.O.; Conrad, C.; Tun-Kyi, A.; Homey, B.; Gombert, M. Boyman, O.; Burg, G.; Liu, Y.J.; Gilliet, M. Plasmacytoid predendritic cells initiate psoriasis through interferon-alpha production. J. Exp. Med. 2005; 202: 135-143.doi: 10.1084/jem.20050500. PMID: 15998792.

35. Gregorio, J.; Meller, S.; Conrad, C.; Di Nardo, A.; Homey, B.; Lauerma, A.; Arai, N.; Gallo, R.L.; Digiovanni, J.; Gilliet, M. Plasmacytoid dendritic cells sense skin injury and promote wound healing through type i interferons. J. Exp. Med. 2010; 207: 29212930. doi: 10.1084/jem.20101102. Epub 2010 Nov 29. PMID: 21115688;

36. Oppmann B, Lesley R, Blom B et al. Novel p19 protein engages IL12 p40 to form a cytokine, IL-23, with biological activities similar as well as distinct from IL-12. Immunity 2000; 13(5): 715-725.doi: 10.1016/s1074-7613(00)00070-4. PMID: 11114383.

37. 38) Parham $C$, Chirica M, Timans J et al. A receptor for the heterodimeric cytokine IL-23 is composed of IL-12Rbeta1 and a novel cytokine receptor subunit, IL-23R. J Immunol 2002; 168(11): 5699-5708.doi: $\quad$ 10.4049/jimmunol.168.11.5699. PMID: 12023369.

38. Pirhonen J, Matikainen S, Julkunen I, Alerts E. Regulation of virus induced IL-12 and IL-23 expression in human macrophages.J.Immunol.2002; 169(10): 567378.doi:10.4049/jimmunol.169.10.5673

39. Ishigame $H$, Kakuta $S$, Nagai $T$ et al. Differential roles of interleukin-17A and -17F in host defense against mucoepithelial bacterial infection and allergic responses. Immunity 2009; 30: 108-119.

40. Teunissen MBM, Koomen CW, De Waal Malefyt R, Wierenga EA, Bos JD. Interleukin-17 and interferon-c synergize in the enhancement of proinflammatory cytokine production by human keratinocytes. J Invest Dermatol 1998; 111: 645-649.

41. Lowes MA, Kikuchi T, Fuentes-Duculan J et al. Psoriasis vulgaris lesions contain discrete populations of Th1 and Th17 T cells. J Invest Dermatol 2008; 128(5): 1207-1211.doi: 10.1038/sj.jid.5701213. Epub 2008 Jan 17. PMID: 18200064.

42. van der Fits L, Mourits $S$, Voerman JS et al. Imiquimod-induced psoriasis-like skin inflammation in mice is mediated via the IL-23/ IL-17axis. J Immunol.2009; 182(9): 5836-5845 doi: 10.4049/jimmunol.0802999. PMID: 19380832.

43. Sonnenberg GF, Fouser LA, Artis D. Border patrol: regulation of immunity, inflammation and tissue homeostasis at barrier surfaces by IL-22. Nat Immunol 2011; 12(5): 383-390. doi: 10.1038/ni.2025; PMID: 21502992.

44. Johnston, A.; Xing, X.; Wolterink, L.; Barnes, D.H.; Yin, Z.; Reingold, L.; Kahlenberg, J.M.; Harms, P.W.; Gudjonsson, J.E. IL-1 and IL-36 are dominant cytokines in generalized pustular psoriasis. J. Allergy Clin. Immunol. 2017, 140(1), 109-120. doi: 10.1016/j.jaci.2016.08.056. Epub 2016 Dec 31. PMID: 28043870 
45. 46) Ashcroft DM, Po AL, Williams HC, Griffiths CE. Systematic review comparative efficacy and tolerability of calcipotriol in treating chronic plaque psoriasis. British MedicalJournal.2000; 320(7240): 963-967. doi:10.1136/bmj.320.7240.963. PMID: 10753146

46. Kragballe K, Gjertsen BT, De Hoop D, Van de Kerkhof PCM, Karlsmark T, Larko O, et al. Double-blind, right/left comparison of calcipotriol and betamethasone valerate in treatment of psoriasis vulgaris. Lancet. 1991; 337(8735): 193-196. doi: 10.1016/01406736(91)92157-w. Erratum in: Lancet 1991 Apr 20; 337(8747): 988. PMID: 1670840.

47. Mason AR, Mason J, Cork M, Dooley G and Edwards G. Topical treatments for chronic plaque psoriasis. Cochrane Database of Systematic Reviews. 2009; 15(2): Art. No.:CD005028. doi: 10.1002/14651858.CD005028.pub2.

48. Update in: Cochrane Database Syst Rev. 2013; 3: CD005028. PMID: 19370616.

49. Morison WL, Marwaha $S$ and Beck L. PUVA-induced phototoxicity: Incidence and causes. Journal of the American Academy of Dermatology. 1997; 36(2 Pt 1): 183-185. doi: 10.1016/s0190-9622(97)70277-9. PMID: 9039165.

50. Wolff K. Side-effects of psoralen photochemotherapy (PUVA). British Journal of Dermatology. 2006; 122(s36): 117-125. doi: 10.1111/j.1365-2133.1990.tb02889.x

51) Cox AJ. Epidermal Dystrophy. Archives of Dermatology. 2011; 115(5): 567.

51. Pearce DJ, Higgins KB, Stealey KH, Balkrishnan R, Crane MM, Camacho $F$, et al. Adverse events from systemic therapies for psoriasis are common in clinical practice. Journal of Dermatological Treatment. 2006; 17(5): 288-293. doi:10.1080/09546630600920041

52. Katz HI, Waalen J and Leach EE. Acitretin in psoriasis: An overview of adverse effects. Journal of the American Academy of Dermatology.1999; 41(Suppl 3): 7-12.doi:10.1016/s01909622(99)70359-2. PMID: 10459140.

53. Sarkar R, Chugh S and Garg V. Acitretin in dermatology. Indian Journal of Dermatology Venereol Leprol. 2013; 79(6): 759-771. doi: 10.4103/0378-6323.120721. PMID: 24177607.

54. Colombo MD, Cassano N, Bellia G and Vena GA. Cyclosporine Regimens in Plaque Psoriasis: An Overview with Special Emphasis on Dose, Duration, and Old and New Treatment Approaches. Scientific World Journal. 2013; 2013: 805705. doi10.1155/2013/805705. PMID: 805705

55. Leman JA and Burden AD. Treatment of severe psoriasis with infliximab. Therapeutics and Clinical Risk Management. 2008; 4(6): 1165-1175. doi-10.2147/tcrm.s3094. PMID:19337424.

56. Mehta BH, Amladi ST. Evaluation of topical $0.1 \%$ tazarotene cream in the treatment of palmoplantarpsoriasis: An observerblinded randomized controlled study. Indian J Dermatol 2011; 56: 40-3. doi: 10.4103/0019-5154.77550. PMID: 21572790

57. Thiers BH.The use of topical calcipotriene/calcipotriol in conditions other than plaque-type psoriasis. J Am Acad Dermato 1997; 37(3 Pt 2): S69-71. PMID: 9344189.

58. Duweb GA, Abuzariba O, Rahim M, al-Taweel M, al-Alem S, Abdulla SA. Occlusive versus nonocclusive calcipotriol ointment treatment for palmoplantar psoriasis. Int J Tissue React 2001; 23(2): 59-62. PMID: 11447774.

59. Adisen E, Tekin O, Gülekon A, Gürer MA. A retrospective analysis of treatment responses of palmoplantar psoriasis in 114 patients. J Eur Acad Dermatol Venereol 2009; 23(7): 814-9. doi: 10.1111/j.1468-3083.2009.03197.x. Epub 2009 Mar 11. PMID: 19470063.
60. Kumar B, Kumar R, Kaur I. Coal tar therapy in palmoplantar psoriasis: Old wine in an old bottle? Int J Dermatol 1997; 36(4): 309-12. doi: 10.1046/j.1365-4362.1997.00176.x. PMID: 9169338.

61. Chen X, Yang $M$, Cheng $Y$, Liu GJ, Zhang $M$. Narrow-band ultraviolet $B$ phototherapy versus broad-band ultraviolet $B$ or psoralen-ultraviolet A photochemotherapy for psoriasis. Cochrane Database Syst Rev 2013 Oct 23(10): CD009481. doi: 10.1002/14651858.CD009481.pub2. PMID: 24151011

62. Carrascosa JM, Plana A, Ferrándiz C. Effectiveness and safety of psoralen-UVA (PUVA) topical therapy in palmoplantar psoriasis: A report on 48 patients. Actas Dermosifiliogr 2013; 104(5): 418-25. doi: 10.1016/j.adengl.2013.04.005. Epub 2013 May 13. PMID: 23680012.

63. Khandpur S, Sharma VK. Comparison of clobetasol propionate cream plus coal tar vs. topical psoralen and solar ultraviolet $A$ therapy in palmoplantar psoriasis. Clin Exp Dermatol 2011; 36(6): 613-6. doi: 10.1111/j.1365-2230.2011.04061.x. Epub 2011 Apr 20. PMID: 21507036.

64. Lozinski A, Barzilai A, Pavlotsky F. Broad-band UVB versus paint PUVA for palmoplantar psoriasis treatment. J Dermatolog Treat 2016; 27(3): 221-3. doi: 10.3109/09546634.2015.1093588. Epub 2015 Oct 20. PMID: 26481287.

65. Goldberg DJ, Chwalek J, Hussain M. 308-nm Excimer laser treatment of palmoplantar psoriasis. J Cosmet Laser Ther 2011; 13(2): 47-9. doi: 10.3109/14764172.2011.564769. PMID: 21401376.

66. Spuls PI, Hadi S, Rivera L, Lebwohl M. Retrospective analysis of the treatment of psoriasis of the palms and soles. J Dermatolog Treat 2003; 14 Suppl 2: 21-5. doi: 10.1080/jdt.14.s2.21.25. PMID: 14578095.

67. Janagond AB, Kanwar AJ, Handa S. Efficacy and safety of systemic methotrexate vs. acitretin in psoriasis patients with significant palmoplantar involvement: A prospective, randomized study. J Eur Acad Dermatol Venereol 2013; 27(3): e384-9. doi: 10.1111/jdv.12004. Epub 2012 Oct 16. PMID: 23066720.

68. Bissonnette R, Pariser DM, Wasel NR, Goncalves J, Day RM, Chen $\mathrm{R}$, et al. Apremilast, an oral phosphodiesterase-4 inhibitor, in the treatment of palmoplantar psoriasis: Results of a pooled analysis from phase II PSOR-005 and phase III Efficacy and Safety Trial Evaluating the Effects of Apremilast in Psoriasis (ESTEEM) clinical trials in patients with moderate to severe psoriasis. J Am Acad Dermatol 2016; 75(1): 99-105. doi: 10.1016/j.jaad.2016.02.1164. Epub 2016 Mar 24. PMID: 27021239.

69. Bissonnette R, Poulin Y, Guenther L, Lynde CW, Bolduc C, Nigen S. Treatment of palmoplantar psoriasis with infliximab: A randomized, double-blind placebo-controlled study. J Eur Acad Dermatol Venereol 2011; 25(12): 1402-8. doi: 10.1111/j.14683083.2011.03984.x. Epub 2011 Feb 23. PMID: 21349113.

70. Poulin Y, Crowley JJ, Langley RG, Unnebrink K, Goldblum OM, Valdecantos WC. Efficacy of adalimumab across subgroups of patients with moderate-to-severe chronic plaque psoriasis of the hands and/or feet: Post hoc analysis of REACH. J Eur Acad Dermatol Venereol 2014; 28(7): 882-90. doi: 10.1111/jdv.12198. Epub 2013 Jun 22. PMID: 23790018;

71. Richetta AG, Mattozzi C, Giancristoforo S, D'Epiro S, Cantisani C, Macaluso L, et al. Safety and efficacy of Adalimumab in the treatment of moderate to severe palmo-plantar psoriasis: An open label study. Clin Ter 2012; 163(2): e61-6. PMID: 22555836.

72. 73) Gottlieb AB. Investigator-initiated, open-label trial of ustekinumab for the treatment of moderate-to-severe palmoplantar psoriasis. J Dermatolog Treat 2013; 24(3): 179-87. doi: 10.3109/09546634.2012.672710. Epub 2012 May 8. PMID: 22390688.

73. Rich P, Sigurgeirsson B, Thaci D, Ortonne JP, Paul C, Schopf RE, et al. Secukinumab induction and maintenance therapy in 
moderate-to-severe plaque psoriasis: A randomized, doubleblind, placebo-controlled, phase II regimen-finding study. $\mathrm{Br} \mathrm{J}$ Dermatol 2013; 168(2): 402-11. doi: 10.1111/bjd.12112. PMID: 23362969.

74. Paul C, Schopf RE, Secukinumab improves hand, foot and nail lesions in moderate-to-severe plaque psoriasis: Subanalysis of a randomized, double-blind, placebo-controlled, regimen-finding phase 2 trial. J Eur Acad Dermatol Venereol 2014; 28: 1670-5.

75. Meyer V, Goerge T, Luger TA, Beissert S. Successful treatment of palmoplantar hyperkeratotic psoriasis with a combination of etanercept and alitretinoin. J Clin Aesthet Dermatol 2011; 4(4): 45-6. PMID:21532878
76. Sandhu K, Kaur I, Kumar B, Saraswat A. , "Efficacy and safety of cyclosporine versus methotrexate in severe psoriasis": a study from north India. J Dermatol. 2003 Jun; 30(6): 458-63. doi: 10.1111/j.1346-8138.2003.tb00416.x. PMID: 12810993.

77. Paik J, Deeks ED. Tofacitinib: A Review in Psoriatic Arthritis. Drugs. 2019 Apr; 79(6): 655-663. doi: 10.1007/s40265-019-01091-3. PMID: 30895473.

78. Schindler CW, (2002); "JAK-STAT signaling in human disease"; J Clin Invest; 2002; 109(9): 1133-7. doi: 10.1172/JCI15644. PMID: 11994400.

Source of Support: The author(s) received no financial support for the research, authorship, and/or publication of this article.

Conflict of Interest: The author(s) declared no potential conflicts of interest with respect to the research, authorship, and/or publication of this article.

For any question relates to this article, please reach us at: editor@globalresearchonline.net New manuscripts for publication can be submitted at: submit@globalresearchonline.net and submit_ijpsrr@rediffmail.com 